\title{
Two new moss records in the family Grimmiaceae from Turkey, Southwest Asia
}

\author{
Mustafa Karakaş and Tülay Ezer* \\ Niğde University, Faculty of Science, Department of Biology, 51100 Niğde-Turkey \\ ${ }^{*}$ Author for correspondence: tuezer@gmail.com, tezer@nigde.edu.tr
}

\begin{abstract}
Grimmia incurva Schwägr. and Schistidium umbrosum (J.E.Zetterst.) H.H. Blom (Grimmiaceae) are reported for the first time from Turkey, Southwest Asia. Turkish plants are described and illustrated from material collected from Göllüdağ Volcano in the Central Anatolia (Niğde) which has a semi-arid, continental climate with a severe frost period in winter.
\end{abstract}

\section{Introduction}

The genus Grimmia is one of the largest groups in the acrocarpous moss family Grimmiaceae. Species of Grimmia are often difficult to identify (Ignatova and Muñoz 2004), and likewise the genus Schistidium has a reputation for being taxonomically difficult. The genus Schistidium currently comprises around 120 species (McIntosh 2007), while Grimmia contains about 95 species (Hastings and Greven 2007).

Grimmia species grow on rocks at low to high altitudes on all continents, and most of them are drought resistant. Therefore, they can withstand extremely harsh cold and dry climates (Ignatova and Muñoz 2004). According to Ros et al. (2013) 29 species of Grimmia have been reported for Turkey. Here we report Grimmia incurva Schwägr. new for Turkey, taking to 30 the number of Grimmia species reported for this country.

Members of the genus Schistidium generally grow on nutrient-rich rocks in arctic to temperate regions (Batan et al. 2013). Nineteen species of Schistidium have been reported for Turkey (Kürschner and Erdağ 2005, Townsend 2005, Tonguç Yayıntaş 2008, 2014, Kürschner and Frey 2011, Batan et al. 2013). Schistidium umbrosum (J.E.Zetterst.) H.H. Blom increases this total by one. Description and illustration of the species further contributes to the moss flora of Turkey.

\section{Material and Methods}

This study is based on specimens collected from Göllüdağ Volcano in the Central Anatolia (Niğde) in May 2015 (Fig. 1) and now held in the Herbarium of Niğde University. The specimens were identified using relevant literature (Blom 1996, Cortini-Pedrotti 2001, Greven, 1995, 2003, Hastings and Greven 2007, Ignatova and Muñoz 2004, Nyholm 1998, McIntosh 2007, Smith 2004). 


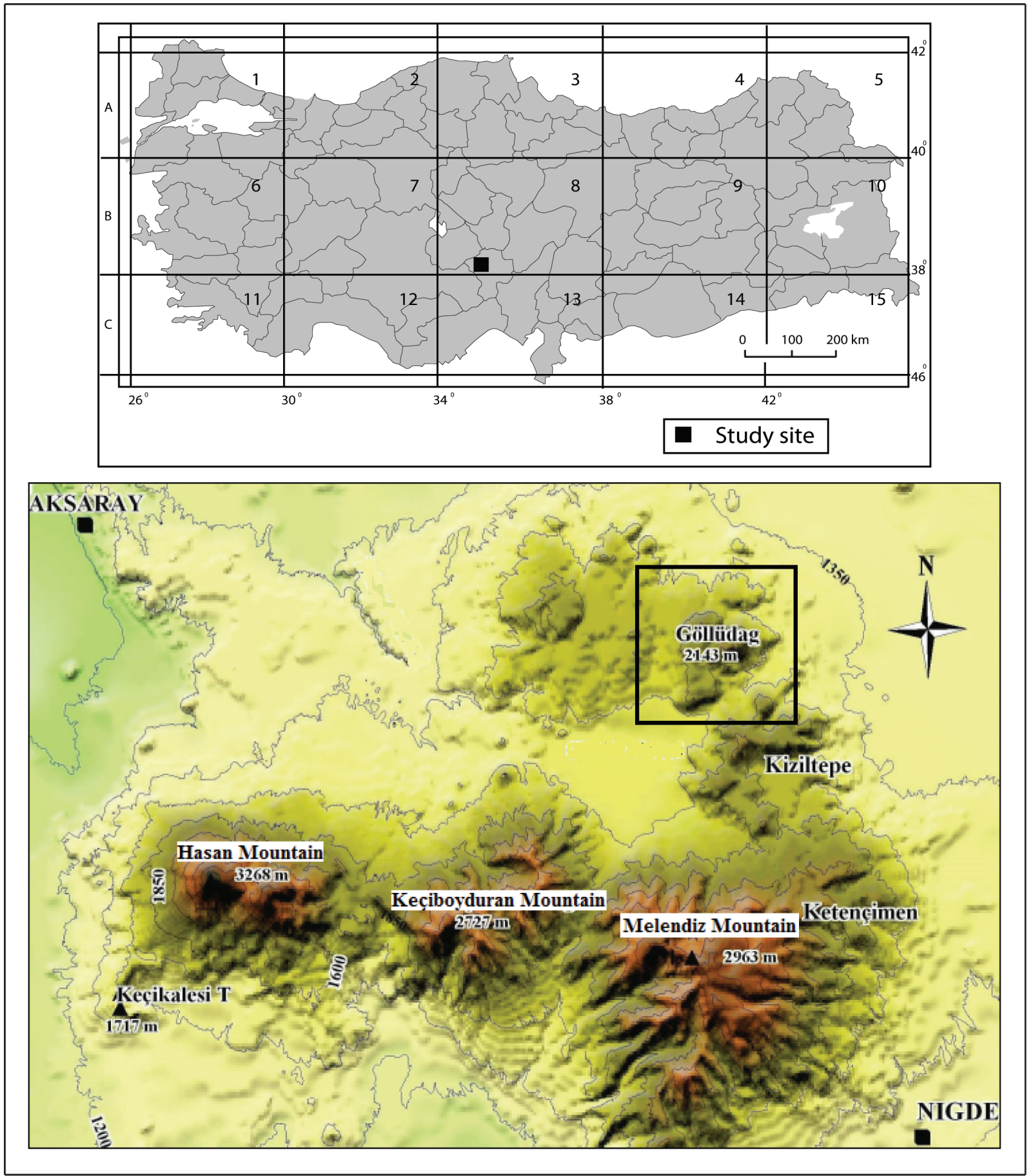

Figure 1. Göllüdağ Volcano region (modified from Bayer Altın 2010)

\section{Taxonomy}

Grimmia incurva Schwägr. Species Muscorum Frondosorum, Schwägrichen, Christian Friedrich Supplementum Primum 1: 90.1811.

Synonyms: G. contorta (Wahlenb.) Arnott, G. curvifolia Lindb., G. hagenii Kaurin, G. torngakiana Bras. \& Hed., G. uncinata Kaulf.

Description of the Turkish specimens: Plants form dark green to blackish rounded cushions. Stems erect $1-2.5 \mathrm{~cm}$ long, occasionally 1-2 branched. Leaves oblong, linear to lanceolate, 2-3 $\mathrm{mm}$ long and $0.5 \mathrm{~mm}$ wide, incurved and moderately contorted and crisped when dry, spreading when moist, tapering to acuminate, with short hyaline apex, sharply keeled distally, margins plane in distal part of leaf, recurved below on one side; lamina mostly bistratose, unistratose near costa and in basal part of leaf; costa differentiated, semi-circular 
in cross-section; upper leaf cells subquadrate, $8-12 \mu \mathrm{m}$; mid-leaf cells rectangular, moderately sinuose and incrassate; basal marginal cells elongate with thin walls and the basal juxtacostal cells are elongate rectangular with thick and porose longitudinal walls. Observed specimens were sterile, no perichaetia, antheridia, or sporophytes. Fig. 2 (1-9).

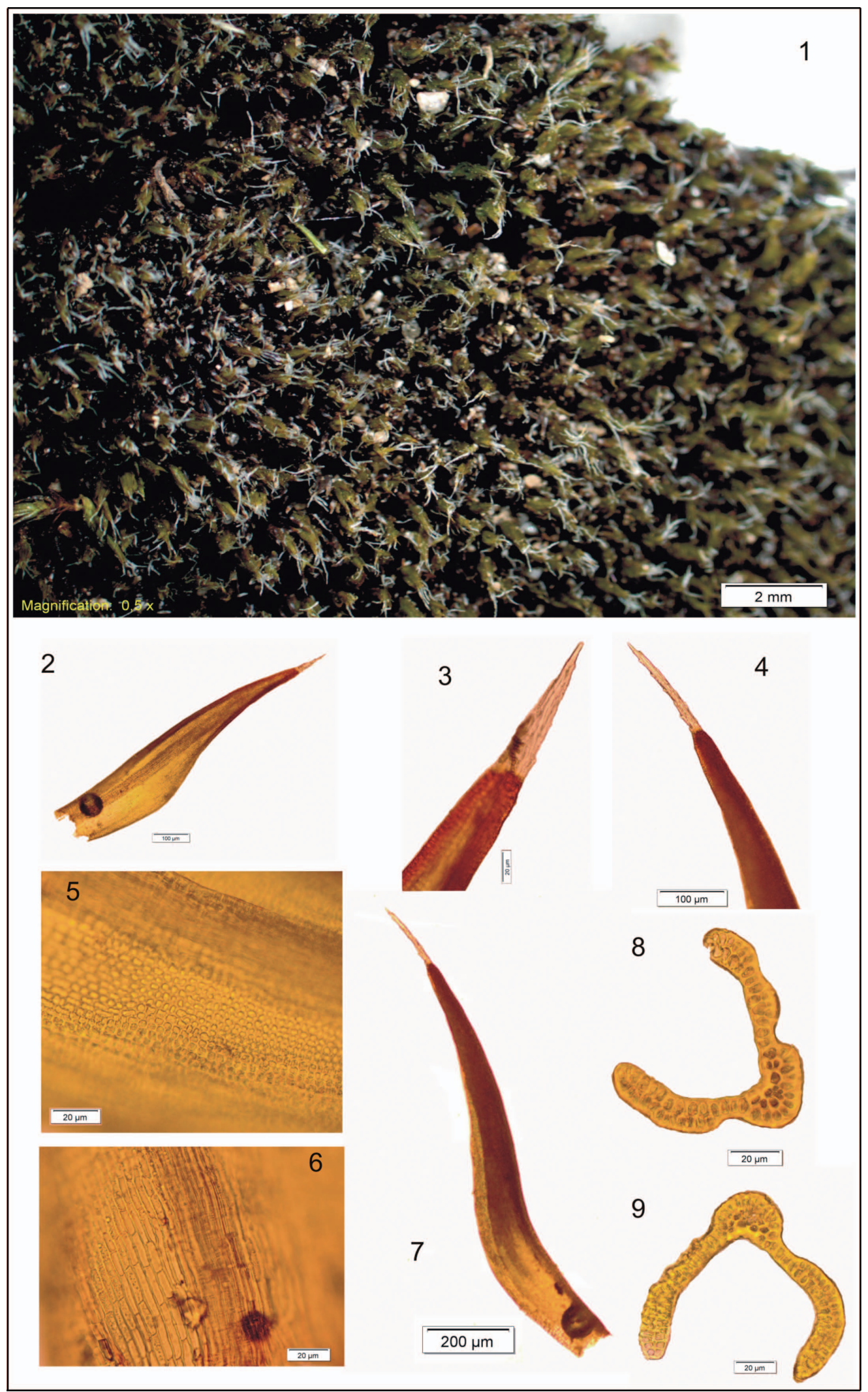

Figure 2. Grimmia incurva (Ezer 1780); 1, habit; 2 and 7, leaf; 3 and 4, leaf apex with hyaline hair-point; 5, upper laminal cells; 6, basal cells; 8 and 9, leaf cross-sections. Scale bars shown. 
Specimen examined: Turkey: Central Anatolia: Niğde: Göllüdağ Volcano, Aşağıseki place, on basaltic rock, alt.

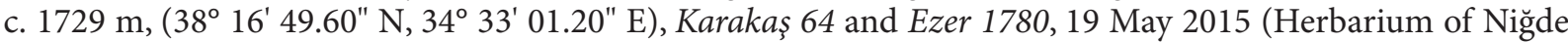
University).

According to the literature (Greven 1995, 2003, Ignatova and Muñoz 2004, Hastings and Greven 2007, Smith 2004), this species is dioicious; capsules very rare, emergent to exserted obloid, yellowish; setae arcuate when moist, 2-3 mm long; operculum rostellate with short beak; peristome teeth orange and strongly perforated; spores $10-12 \mu \mathrm{m}$; calyptra mitrate.

Grimmia donniana Smith, G. elongata G. Kaulfuss and G. fuscolutea Hook., are similar species to G. incurva. Linear-lanceolate, contorted to almost crisped leaves with a short hair-point are characteristic of G. incurva while G. fuscolutea has slightly flexuose leaves with a long hair-point. Grimmia elongata has a unistratose lamina, whereas lamina of G. incurva is mostly bistratose, unistratose near costa and in basal part of leaf. Also, Grimmia donniana has thin-walled basal marginal cells and usually numerous exserted capsules. Grimmia incurva may superficially resemble Andreaea members and Dicranoweisia crispula in the field, but G. incurva differs from them by the presence of short hair-points. Comparison of the main different and similar characters between Turkish specimens and some other collections are listed in Table 1.

Table 1. Comparison of Turkish Grimmia incurva specimens and other collections.

\begin{tabular}{|c|c|c|c|c|}
\hline & Turkish plants & $\begin{array}{l}\text { Russian plants (Ignatova } \\
\text { and Muñoz 2004) }\end{array}$ & $\begin{array}{l}\text { European plants } \\
\text { (Greven 1995) }\end{array}$ & $\begin{array}{l}\text { North American plants } \\
\text { (Hastings and Greven } \\
\text { 2007) }\end{array}$ \\
\hline Plants & $\begin{array}{l}\text { dark green to blackish, } \\
1-2.5 \mathrm{~cm} \text { long }\end{array}$ & $\begin{array}{l}\text { dark green or blackish- } \\
\text { green, }(1-) 2-3 \mathrm{~cm} \text { long }\end{array}$ & $\begin{array}{l}\text { dark green or blackish- } \\
\text { green, } 1-3 \mathrm{~cm} \text { long }\end{array}$ & green to blackish, $1-2 \mathrm{~cm}$ \\
\hline Leaves shape & $\begin{array}{l}\text { oblong, linear to } \\
\text { lanceolate }\end{array}$ & linear-laceolate & linear & oblong to linear-lanceolate \\
\hline Leaf length & $2-3 \times 0.5 \mathrm{~mm}$ & $\begin{array}{c}(1-) 2.5-3(-4) \times(0.3-) \\
0.4-0.6 \mathrm{~mm}\end{array}$ & $2-5 \mathrm{~mm}$ & $2.5-4.5 \times 0.3-0.5 \mathrm{~mm}$ \\
\hline Hyaline hair-point & short & short to absent & short & short, occasionally long \\
\hline Lamina & $\begin{array}{l}\text { mostly bistratose, } \\
\text { unistratose near costa }\end{array}$ & $\begin{array}{l}\text { mostly bistratose in distal } \\
1 / 3, \text { unistratose near costa }\end{array}$ & partly bistratose above & $\begin{array}{l}\text { distal laminal cells } 1 \text {-stratose, } \\
\text { margins and apex } 2 \text {-stratose }\end{array}$ \\
\hline Costa & $\begin{array}{l}\text { semi-circular in cross- } \\
\text { section }\end{array}$ & $\begin{array}{l}\text { strongly prominent } \\
\text { dorsally, semi-circular } \\
\text { in cross-section, with } 2 \\
\text { ventral epidermal cells }\end{array}$ & $\begin{array}{l}\text { projecting on dorsal } \\
\text { side }\end{array}$ & projecting on abaxial side \\
\hline $\begin{array}{l}\text { Upper and mid- } \\
\text { leaf cells }\end{array}$ & $\begin{array}{c}\text { subquadrate, } \\
\text { moderately sinuose and } \\
\text { incrassate, } 8-12 \mu \mathrm{m}\end{array}$ & $\begin{array}{l}\text { subquadrate, slightly } \\
\text { sinuose walls, 9-14 } \mu \mathrm{m}\end{array}$ & $\begin{array}{l}\text { shortly rectangular, } \\
\text { sinuosely incrassate, } \\
\text { 9-15 } \mu \mathrm{m}\end{array}$ & $\begin{array}{l}\text { rectangular, slightly sinuose, } \\
\text { thick-walled }\end{array}$ \\
\hline $\begin{array}{l}\text { Basal marginal } \\
\text { cells }\end{array}$ & elongate with thin walls & slightly shorter & rectangular, hyaline & $\begin{array}{l}\text { short to long rectangular, } \\
\text { thin-walled }\end{array}$ \\
\hline $\begin{array}{l}\text { Basal juxtacostal } \\
\text { cells }\end{array}$ & $\begin{array}{l}\text { elongate rectangular } \\
\text { with thick and porose } \\
\text { longitudinal walls }\end{array}$ & $\begin{array}{l}\text { elongate rectangular } \\
\text { with thick and porose } \\
\text { longitudinal walls and } \\
\text { transverse walls }\end{array}$ & nodular thickenings & $\begin{array}{l}\text { long rectangular, thick- } \\
\text { walled }\end{array}$ \\
\hline Sporophyte & unknown & rare & regularly present & occasionally present \\
\hline
\end{tabular}

Ecology and distribution: Grimmia incurva usually grows on acidic rock at moderate to high elevations. It is one of the characteristic species of the alliance Andreaeion rupestris (Greven 1995, Dierssen 2001). In Turkey Grimmia incurva was collected on basaltic rock surface from Göllüdağ Volcano (Niğde). It was found together with the moss species Bryum dunense A. J. E. Sm \& H. Whitehouse and Grimmia orbicularis Bruch ex Wilson. Grimmia incurva is distributed in Europe (Austria, Azores, Bulgaria, France, Germany, Italy, Macedonia, Scotland, Slovakia, Spain, Sweden, Switzerland), Asia (Central China, Japan, Mongolia, Russia (Altai Mts., Caucasia, Chukotka, Kamchatka, Khabarovsk Territory, Kola Peninsula, Magadan Province, Middle and South Urals, Yakutia), America (Mexico, North America), and Greenland (Greven 1995, 2003, Ros et al. 2013, Ignatova and Muñoz 2004, Hastings and Greven 2007).

Schistidium umbrosum (J.E.Zetterst.) H.H. Blom. Blom, Hans Haavardsholm, Bryophytorum Bibliotheca 49: 125. 1996.

Basionym: Grimmia apocarpa fo. umbrosa J.E.Zetterst. 
Description of the Turkish specimens: Plants form small, dense cushion or tufts, greyish green or olivaceousgreen in upper parts, brown to black in lower parts. Stems slender, up to $2.5 \mathrm{~cm}$, intricately branched, central strand distinct. Leaves sharply keeled in upper part, slightly curved or straight, acute, $1.7 \mathrm{~mm}$ long, $0.6 \mathrm{~mm}$ wide, hair point very shortly decurrent, $0.3 \mathrm{~mm}$, rather coarse, shortly decurrent, sharply spinulose-denticulate; margins smooth, recurved towards apex, bistratose in upper part; lamina smooth, unistratose, less frequently bistratose in upper part; laminal cells irregular in shape, thick-walled, sinuose, upper leaf cells $8 \mu \mathrm{m}$ wide, oval to shortly oblong; basal leaf cells incrassate, rectangular, 25-30 $\mu \mathrm{m}$; costa widened above and central parts, widened just below apex, excurrent or percurrent, smooth or with few low papillae near apex; sporophytes common, and immersed; seta thick, $0.25 \mathrm{~mm}$ long; capsule orange-brown, cupulate, $0.7 \times 0.8 \mathrm{~mm}$; exothecial cells thin-walled, isodiametric and transversely elongated; peristome teeth orange-brown to brownish red, recurved, from broad base and abruptly contracted to a fine point, 280-310 $\mu \mathrm{m}$ long, strongly perforated, coarsely papillose; spores $12-14 \mu \mathrm{m}$, finely granulose. Fig. 3 (1-13).

Specimens examined: Central Anatolia. Niğde: Göllüdağ Volcano, Sarıkaya place, on basaltic rock, alt. c. 1936 m, (38 15' 52.60" N 34 33' 57.50" E), Karakaş 90 and Ezer 1789, 6 September 2015 (Herbarium of Niğde University).

Schistidium umbrosum is closely related to S. pulchrum which was reported for Turkey from the Erciyes Mountain by Kara et al. (2014). Schistidium pulchrum has an oblong-cylindrical urn, whereas Schistidium umbrosum has a cupulate, obovoid, or subsphaerical urn. Also, the dull reddish-brown strongly perforated and coarsely papillose peristome teeth of S. umbrosum distinguish this species from S. pulchrum. Comparison of the main different and similar characters between Turkish specimens and some other collections of $S$. umbrosum are listed in Table 2.

Table 2. Comparison of Turkish Schistidium umbrosum specimens and other collections.

\begin{tabular}{|c|c|c|c|}
\hline & Turkish plants & $\begin{array}{l}\text { Norwegian and Swedish plants } \\
\text { (Blom 1996) }\end{array}$ & Nordic plants (Nyholm 1998) \\
\hline Plants & small, up to $2.5 \mathrm{~cm}$ & small, $0.8-3.5 \mathrm{~cm}$ & small, $0.8-3.5 \mathrm{~cm}$ \\
\hline Leaves & $\begin{array}{l}1.7 \times 0.6 \mathrm{~mm} \text {, sharply keeled in } \\
\text { upper part }\end{array}$ & $\begin{array}{l}(1.0-) 1.2-1.9(-2.1) \times(0.3) 0.4-0.75 \\
\mathrm{~mm} \text {, sharply keeled in upper part }\end{array}$ & $\begin{array}{l}(1.0-) 1.2-1.9(-2.1) \times(0.3) 0.4-0.75 \\
\mathrm{~mm} \text {, sharply keeled in upper part }\end{array}$ \\
\hline Hair point & very shortly decurrent, $0.3 \mathrm{~mm}$ & $\begin{array}{l}\text { not or very shortly decurrent, } \\
0-0.4(-0.7) \mathrm{mm}\end{array}$ & $\begin{array}{l}\text { not or very shortly decurrent, } \\
0-0.4(-0.7) \mathrm{mm}\end{array}$ \\
\hline Margins & smooth, bistratose in upper part & $\begin{array}{l}\text { smooth or rarely denticulate in } \\
\text { apical part, in upper and central } \\
\text { parts bistratose }\end{array}$ & $\begin{array}{l}\text { smooth, rarely denticulate below } \\
\text { apex, in upper and central parts } \\
\text { bistratose }\end{array}$ \\
\hline Lamina & $\begin{array}{l}\text { smooth, unistratose, less frequently } \\
\text { bistratose in upper part }\end{array}$ & $\begin{array}{l}\text { smooth, in upper and central parts } \\
\text { unistratose with few to several } \\
\text { bistratose spots }\end{array}$ & $\begin{array}{l}\text { smooth, unistratose or patly } \\
\text { bistratose in upper part }\end{array}$ \\
\hline Laminal cells & $\begin{array}{l}\text { irregular in shape, thick-walled, } \\
\text { sinuose }\end{array}$ & $\begin{array}{l}\text { gradually becoming shorter } \\
\text { towards apex, irregular in shape, } \\
\text { thick-walled, } \pm \text { sinuose }\end{array}$ & $\begin{array}{l}\text { irregular in shape (transversely } \\
\text { ovate to shortly oblong), } \\
\text { incrassate, } \pm \text { sinuose }\end{array}$ \\
\hline Upper leaf cells & $8 \mu \mathrm{m}$ wide, oval to shortly oblong & $\begin{array}{l}\text { (6)7-9 } \mu \mathrm{m} \text {, transversely oval to } \\
\text { shortly oblong }\end{array}$ & (6)7-9 $\mu \mathrm{m}$ wide \\
\hline Basal leaf cells & rectangular, 25-30 $\mu \mathrm{m}$ long & shortly oblong, up to $20-41 \mu \mathrm{m}$ & up to $20-40 \mu \mathrm{m}$ \\
\hline Costa & $\begin{array}{l}\text { widened just below apex, } \\
\text { excurrent or percurrent }\end{array}$ & $\begin{array}{l}\text { often widened just below apex, } \\
\text { excurrent or rarely percurrent }\end{array}$ & often widened just below apex \\
\hline Sporophytes & common, and immersed & $\begin{array}{l}\text { commonly present, mostly deeply } \\
\text { immersed }\end{array}$ & unreported \\
\hline Urn & $\begin{array}{l}\text { orange-brown, cupulate, } \\
0.7 \times 0.8 \mathrm{~mm}\end{array}$ & $\begin{array}{l}\text { straw yellow to light orange- } \\
\text { brown, cupulate or broadly ovoid, } \\
0.55-0.75-1.0 \times 0.5-0.8 \mathrm{~mm}\end{array}$ & $\begin{array}{l}\text { straw yellow to light orange- } \\
\text { brown, cupulate or broadly ovoid, } \\
0.55-1.0 \times 0.5-0.8 \mathrm{~mm}\end{array}$ \\
\hline Exothecial cells & $\begin{array}{l}\text { thin-walled, isodiametric and } \\
\text { transversely elongated }\end{array}$ & $\begin{array}{l}\text { In patches of short transversely } \\
\text { rectangular, square and shortly } \\
\text { rectangular, thin-walled }\end{array}$ & $\begin{array}{l}\text { predominantly isodiametric and } \\
\text { transversely elongated }\end{array}$ \\
\hline Peristome teeth & $\begin{array}{l}\text { orange-brown to brownish red, } \\
\text { recurved, strongly perforated, } \\
280-310 \mu \mathrm{m}\end{array}$ & $\begin{array}{l}\text { dull, dark orange-brown to } \\
\text { brownish red, } \pm \text { straight and } \\
\text { twisted once around the axis, } \\
\text { strongly perforated to fenestrate in } \\
\text { upper half, }(260) 280-390 \\
(-420) \mu \mathrm{m}\end{array}$ & $\begin{array}{l}\text { dark orange-brown to brownish } \\
\text { red, strongly perforated in upper } \\
\text { half, (260)280-390(-420) } \mu \mathrm{m}\end{array}$ \\
\hline Spores & 12-14 $\mu \mathrm{m}$, finely granulose & (8)10-13(-15) $\mu \mathrm{m}$, finely granulose & $10-13(-15) \mu m$, finely granulose \\
\hline
\end{tabular}




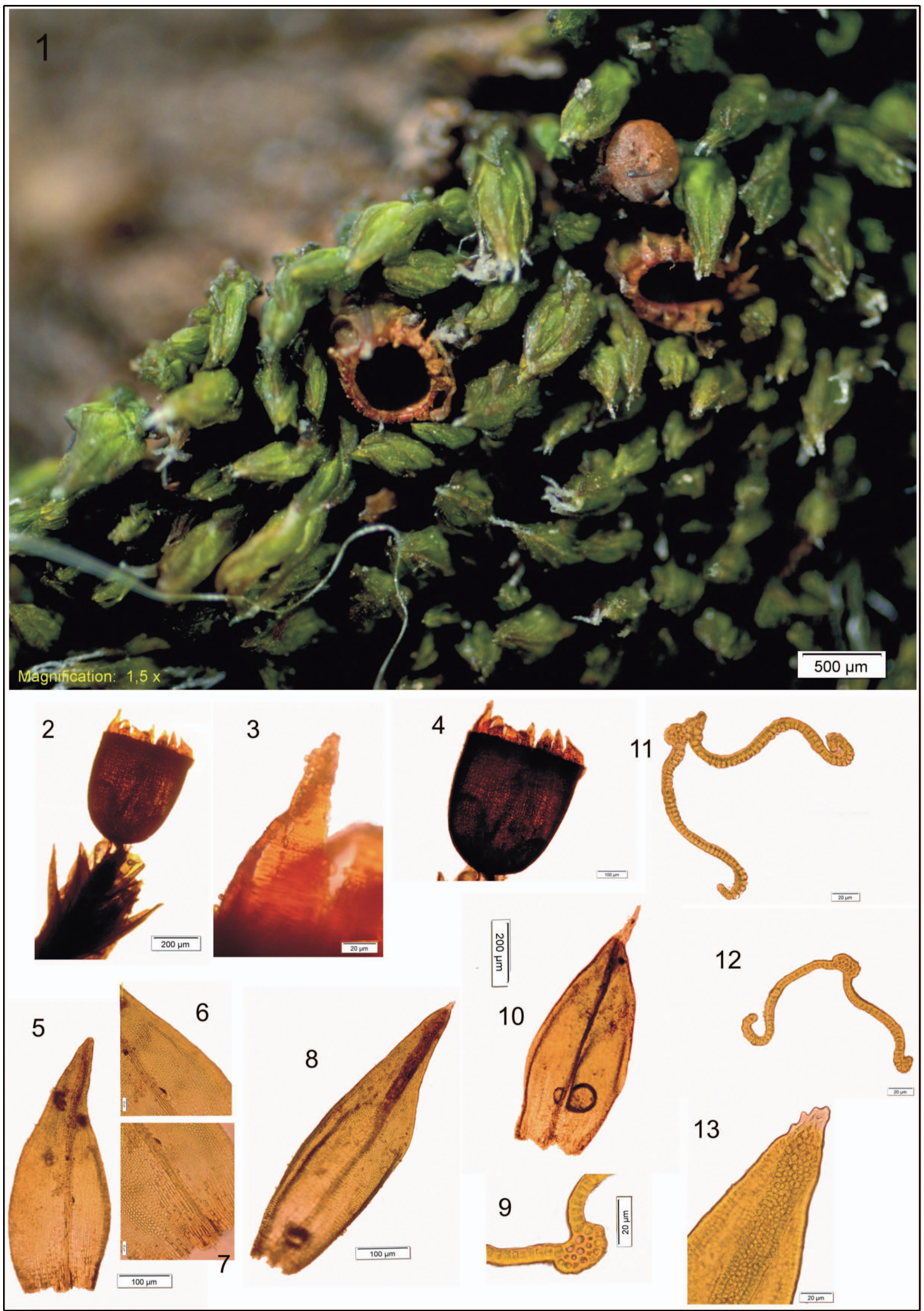

Figure 3. Schistidium umbrosum (Ezer 1780); 1, habit; 2, sporophyte; 3, peristome teeth; 4, urn; 5 and 8, leaves; 6, median leaf cells; 7, basal leaf cells; 9, cross-section of costa; 10, perichaetial leaf; 11 and 12, leaf cross-section; 13, leaf apex. Scale bars shown. 
Ecology and distribution: Schistidium umbrosum is subneutrophytic [pH 5.7-7.0 (-7,5)], mesophytic, sciophytic. The species prefers vertical or overhanging cliffs of base-rich rocks like hard schists and calcareous sandstone in the subalpine and alpine regions. It is one of the characteristic species of the alliance Grimmion tergestinae (Nyholm 1998, Dierssen 2001). In Turkey Schistidium umbrosum was collected on basaltic rock surface from Göllüdağ Volcano (Niğde). It was found together with the moss species Grimmia alpestris (Web. \& Mohr) Schleich. and Pseudoleskea incurvata (Hedw.) Loeske. Schistidium umbrosum is distributed in the Alps, Austria, Bosnia-Herzegovina, Canada, Central Norway, Georgia, Greenland, Montenegro, Northern Sweden, NW Finland, North America, Slovakia, Svalbard, and Switzerland (Blom 1996, Nyholm 1998, Ros et al. 2013).

\section{Acknowledgements}

We are indebted to the Niğde University, Research Project Units (Project Number: FEB2015/35) for financial support.

\section{References}

Batan N, Alataş M, Özdemir T (2013) Schistidium sordidum New to Turkey and Southwest Asia. Archives of Biological Sciences 65: 1505-1509 http://dx.doi.org/10.2298/ABS1304505B

Bayer Altın T (2010) Hasandağı ve Melendiz Dağı Çevresinde Topografik Faktörlere Göre Yayla ve Ağılların Dağılışı. Coğrafi Bilimler Dergisi 8: 189-211

Blom HH (1996) A revision of the Schistidium apocarpum complex in Norway and Sweden. Bryophytorum Bibliotheca 49: 333

Cortini-Pedrotti C (2001) Flora dei muschi d'Italia. Sphagnosida, Andreaeopsida, Bryopsida (I parte). Roma, Antonio Delfino Editore

Dierßen K (2001) Distribution, ecological amplitude and phytosociological characterization of European bryophytes. Bryophytorum Bibliotheca 56: 1-289

Greven HC (1995) Grimmia Hedw. (Grimmiaceae, Musci) in Europe. pp 159, Backhuys Publishers, Leiden, The Netherlands

Greven HC (2003) Grimmias of the World.pp 247, Backhuys Publishers, Leiden

Hastings RI, Greven HC (2007) 2. Grimmia - In: Crosby, M. R., Delgadillo, C. M., Harris, P. et al. (eds), Flora of North America. Volume 27. Bryophytes: Mosses, part 1. pp 225-258, Oxford Univ. Press

Ignatova E, Muñoz J (2004) The genus Grimmia Hedw. (Grimmiaceae, Musci) in Russia. Arctoa 13: 101-182

Kara R, Ezer T, Can Gözcü M, Bozdoğan ŞG (2014) Bryophyte flora of Erciyes Mountain in Turkey, with 6 bryophyte records from the country. Turkish Journal of Botany 38: 763-781 http://dx.doi.org/10.3906/bot1311-25

Kürschner H, Erdağ A (2005) Bryophytes of Turkey: An Annotated Reference List of the Species with Synonyms from the Recent Literature and an Annotated List of Turk-ish Bryological Literature. Turkish Journal of Botany 29: 95-154

Kürschner H, Frey W (2011) Liverworts, mosses and hornworts of Southwest Asia (Marchantiophyta, Bryophyta, Anthocerotophyta). Nova Hedwigia Supplement 139: 1-240

McIntosh T (2007). 1. Schistidium - In: Crosby, M. R., Delgadillo, C. M., Harris, P. et al. (eds), Flora of North America. Volume 27. Bryophytes: Mosses, part 1. pp 207-225, Oxford Univ. Press

McIntosh T, Blom HH, Toren DR, Shevock JR (2015) Two new species of Schistidium (Grimmiaceae, Bryophyta) from western North America. Phytotaxa 213:57-64 http://dx.doi.org/10.11646/phytotaxa.213.1.5

Nyholm E (1998) Illustrated Flora of Nordic Mosses, Fasc. 4. Aulacomniaceae - Meesiaceae - Catocopiaceae - Bartra-miaceae - Timmiaceae - Encalyptaceae - Grimmiaceae - Ptychomitriaceae - Hedwigiaceae Orthotrichaceae. pp 145-244, The Nordic Bryological Society. Lund

Ros RM, Mazimpaka V, Abou-Salama U, Aleffi M, Blockeel TL, Brugués M, Cros RM, Dia MG, Dirkse G, Draper I, El-Saadawi W, Erdağ A, Ganeva A, Gabriel RMA, Gonzáles-Mancebo JM, Granger C, Herrnstadt I, Hugonnot V, Khalil K, Kürschner H, Losada-Lima A, Luís L, Mifsud SD, Privitera M, Puglisi M, Sabovljević M, Sérgio C, Shabbara HM, Sim-Sim M, Sotiaux A, Tacchi A, Vanderpoorten A, Werner O (2013) Mosses of the Mediterranean, anannotated checklist. Cryptogamie, Bryologie 34: 99-283 http://dx.doi.org/10.7872/ cryb.v34.iss2.2013.99

Smith AJE (2004) The Moss Flora of Britain and Ireland. 2nd ed. Cambridge: Cambridge University Press http://dx.doi.org/10.1017/CBO9780511541858

Tonguç Yayıntaş Ö (2008) Schistidium agassizii (Grimmiaceae, Bryopsida) new to southern Turkey. Flora Mediterranea 18: 117-121 
Tonguç Yayıntaş Ö (2014) Contributions to the Moss Flora of Western Turkey: Biga Peninsula (Canakkale) and Thrace Region of Turkey. Global Journal of Science Frontier Research: C Biological Science Vol 14, No 3-C

Townsend CC (2005) Mosses from the Caucasian region and eastern Turkey, Journal of Bryology 27: 143-152 http://dx.doi.org/10.1179/037366805X53068

Manuscript recieved 17 January 2016, accepted 27 April 2016 